\title{
Aspects of the ecology of Penelope superciliaris temminck, 1815 (Aves: Cracidae) in the Araripe National Forest, Ceará, Brazil
}

\author{
T. N. Thel ${ }^{a *}$, P. H. R. Teixeira ${ }^{a}$, R. M. Lyra-Neves ${ }^{a, b}$, W. R. Telino-Júnior ${ }^{a, b}$, \\ J. M. R. Ferreira ${ }^{a}$ and S. M. Azevedo-Júnior ${ }^{a, c}$ \\ aPrograma de Pós-graduação em Ecologia, Departamento de Biologia, Universidade Federal Rural de Pernambuco - UFRPE, \\ Av. Dom Manoel de Medeiros, s/n, Dois Irmãos, CEP 52171-900, Recife, PE, Brazil

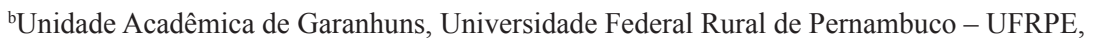 \\ Av. Bom Pastor, s/n, Boa Vista, CEP 55292-270, Garanhuns, PE, Brazil \\ ${ }^{\mathrm{c}}$ Departamento de Biologia, Universidade Federal Rural de Pernambuco - UFRPE, Av. Dom Manoel de Medeiros, s/n, \\ Dois Irmãos, CEP 52171-900, Recife, PE, Brazil \\ *e-mail: thiago_thel@yahoo.com.br
}

Received: April 25, 2014 - Accepted: June 30, 2014 - Distributed: November 30, 2015

(With 3 figures)

\begin{abstract}
Guans are large frugivorous birds that inhabit Neotropical forests and play a fundamental role in seed dispersal and forest regeneration. Despite their ecological importance, the natural populations of these birds are increasingly threatened by deforestation and hunting pressure. The present study was conducted in the Araripe National Forest, Ceará (Brazil), with the objective of estimating population parameters (density and total population size) in the Rusty-margined Guan (Penelope superciliaris) and the White-browed Guan (Penelope jacucaca), as well as providing data on their feeding ecology, including seasonal variation and fruit morphology. The study was based on the monthly collection of data between November, 2011, and October, 2012. Population parameters were estimated using line transect surveys, while feeding ecology was studied by direct observation, and the collection of plant and fecal samples. The estimated population density of $P$. superciliaris was 19.17 individuals $/ \mathrm{km}^{2}(\mathrm{CV}=13.98 \%)$, with a mean of 0.13 sightings per $10 \mathrm{~km}$ walked. Penelope jacucaca was not encountered during the surveys. A total of 14 plant species were recorded in the diet of $P$. superciliaris, 12 by direct observation, and two from fecal samples. Fruit diameter varied from $6.3 \pm 1.35 \mathrm{~mm}$ (Miconia albicans) to $29.9 \pm 1.7 \mathrm{~mm}$ (Psidium sp.). Yellow was the most frequent fruit color $(41.6 \%$, $\mathrm{n}=5)$, with two species each (16.6\%) providing black, green, and red fruits. Fleshy fruits of the baccate $(50.0 \%, \mathrm{n}=6)$ and drupe $(33.3 \%$, $\mathrm{n}=4$ ) types were the most consumed. The data on population parameters and feeding ecology collected in the present study provide an important database for the development of effective management strategies by environmental agencies for the conservation of the populations of the two guan species.
\end{abstract}

Keywords: density, abundance, cracids, feeding and conservation.

\section{Aspectos ecológicos de Penelope superciliaris temminck, 1815 (Aves: Cracidae) na Floresta Nacional do Araripe, Ceará, Brasil}

\begin{abstract}
Resumo
Os jacus pertencem ao grupo das grandes aves florestais frugívoras e desempenham um papel fundamental na dispersão de sementes e na manutenção das florestas tropicais. Apesar da importância desse grupo, a destruição de habitats e a caça predatória vêm ameaçando as populações naturais dessas aves. Esse trabalho foi realizado na Floresta Nacional do Araripe (FLONA-Araripe) e teve como objetivos estimar os parâmetros populacionais de densidade, abundância e tamanho populacional de Penelope superciliaris (jacupemba) e Penelope jacucaca (jacucaca), coletar informações sobre a ecologia alimentar dessas espécies nas estações seca e chuvosa e caracterizar morfologicamente os frutos consumidos por essas espécies. O trabalho foi desenvolvido entre novembro de 2011 e outubro de 2012. Foram utilizados os métodos de transectos lineares, para estimar os parâmetros populacionais, além de registros visuais, coleta de material botânico e de amostras de fezes para estudar a ecologia alimentar. Foi registrada uma densidade de 19.17 indivíduos $/ \mathrm{km}^{2}$ com um $\mathrm{CV}=13.98 \%$ e uma abundância de 0.13 encontros $/ 10 \mathrm{~km}$ para P superciliaris. Penelope jacucaca não foi registrada no estudo e nenhum dado ecológico foi coletado. Foi registrado também o consumo de 14 espécies de plantas, 12 delas detectadas por registros visuais e duas por amostras de fezes. O diâmetro dos frutos consumidos variou entre $6.3 \pm 1.35 \mathrm{~mm}$ (Miconia albicans) a $29.9 \pm 1.7 \mathrm{~mm}$ (Psidium sp.). Espécies com os frutos amarelos foram as mais consumidas $(n=5 ; 41.6 \%)$, seguidos por frutos negros, verdes e vermelhos $(n=2 ; 16.6 \%)$ cada.
\end{abstract}


Os frutos carnosos do tipo bacóide $(n=6 ; 50 \%)$ e drupóide $(n=4 ; 33.3 \%)$ foram os mais consumidos. Os dados sobre os parâmetros populacionais e ecologia alimentar contribuem de forma positiva na criação de estratégias de manejo e conservação, as quais poderão ser utilizadas pelos órgãos ambientais a fim de desenvolver ações de conservação que envolva estas duas espécies.

Palavras-chave: densidade, abundância, cracídeos, alimentação e conservação.

\section{Introduction}

The guans (Penelope spp.) represent the most diverse genus of the family Cracidae, with a total of 15 species (Sick, 2001). The Rusty-margined Guan, Penelope superciliaris Temminck, 1815, is the smallest member of this family, and inhabits lowland rainforests, as well as other habitats, such as caatinga scrub, savanna woodland, secondary forests, and lake and river margins (Sick, 2001). This guan is one of the few cracids able to survive in small forest remnants (Mikich, 2002). The White-browed Guan, Penelope jacucaca Spix, 1825, is the largest cracid found in the Caatinga scrublands of northeastern Brazil, and is considered to be threatened with extinction by Machado et al. (2008), due primarily to the loss of habitat and hunting pressure.

As large-bodied frugivores, guans play a fundamentally important role in the regeneration of forests through seed dispersal, and are also used as a subsistence resource by the rural and indigenous populations of the Neotropics (Rios et al., 2008; Bernardo and Desbiez, 2011; Bernardo et al., 2011). As they are able to ingest relatively large fruits, these birds help to disperse plants with large seeds that tend to be the most vulnerable to extinction due to the reduced diversity of frugivores capable of dispersing these seeds, especially in disturbed habitats. These birds may thus be essential for the maintenance of tropical forests (Silva and Tabarelli, 2000).

A number of studies have shown that cracids contribute the greatest biomass of birds harvested by hunters in the Neotropics (Silva and Strahl, 1991). Many endemic forest species, such as guans and curassows, are particularly vulnerable to these threats (Brooks and Strahl, 2000; Brooks and Fuller, 2006). However, few data are available on the ecology, population biology or hunting patterns of these birds, constituting a major challenge for the development of effective conservation measures (Brasil, 2008).

Both the guan species targeted by the present study (Penelope jacucaca and Penelope superciliaris) are important components of the fauna of the Araripe National Forest in northeastern Brazil, where they suffer critical levels of impact from human activities (Nascimento et al., 2000). Given the general lack of data on cracid ecology, reliable information on the characteristics of the populations of these guans in this protected area are urgently needed in order to guarantee the development of effective conservation and management measures. Given this, the present study aimed to provide estimates of population parameters (abundance, density, and total population size) for P. jacucaca and P. superciliaris in the Araripe National Forest, as well as data on feeding ecology, including seasonal variation, and the morphometric characteristics of the fruits exploited by these species.

\section{Material and Methods}

\subsection{Study area}

The Araripe-Apodi National Forest is located within the APA-Araripe in southern Ceará, between latitudes $07^{\circ} 11^{\prime} 42^{\prime \prime} \mathrm{S}$ and $07^{\circ} 28^{\prime} 38^{\prime \prime} \mathrm{S}$ and longitudes $39^{\circ} 13$ ' $28^{\prime \prime} \mathrm{W}$ and $39^{\circ} 36^{\prime} 33^{\prime \prime} \mathrm{W}$. This conservation unit has a total area of approximately 38,626 ha, and includes parts of the municipalities of Barbalha, Crato, Nova Olinda, Jardim, Missão Velha, and Santana do Cariri, all located in the Brazilian state of Ceará (Brasil, 2004). This conservation unit includes areas of cloud forest, savanna, savanna woodland, and carrasco scrub (Austregesilo Filho et al., 2001). The climate of the Araripe National Forest is tropical rainy, with mean annual precipitation of $1368 \mathrm{~mm}, 80 \%$ of which is concentrated in the rainy season, between December and April, with a peak in March. The dry season lasts between five and seven months, peaking in September, which is usually the hottest and driest month (Brasil, 2004).

The study area was delimited by the survey transects and adjacent areas. The area was estimated based on the geometric figures formed by the transects - an equilateral triangle and a right-angled triangle. The research reported here was authorized by the Brazilian government through permit number 29970-3 emitted by the Biodiversity Authorization and Information System (SISBIO).

\subsection{Survey of guan populations}

Quantitative data on the guan populations were collected in line transect surveys, using the standard procedures developed for the study of Neotropical vertebrate faunas (Buckland et al., 2001; Cullen Junior and Rudran, 2003). The surveys were based on standardized walks of the pre-established transects at a constant speed of no more than $1 \mathrm{~km} / \mathrm{h}$ (Buckland et al., 1993). Distance sampling depends on five basic assumptions: (a) all animals on the trail are detected; (b) the perpendicular distances are measured with the maximum possible precision; (c) all animals are detected before they move; (d) all sightings are independent events, and (e) the same animal is not detected more than once during a given survey (Buckland et al., 2001; Cullen Junior and Rudran, 2003).

For each sighting of a guan, the following data were recorded (see Cullen Junior and Rudran, 2003): (a) date and time; (b) species; (c) number of individuals sighted; 
(d) perpendicular distance between the animal or group and the transect (using a surveyor's measuring tape).

The surveys were conducted along two existing transects of $4 \mathrm{~km}$ in length (Figure 1) that traverse the natural vegetation of the National Forest. The transects were walked between 05:00 $\mathrm{h}$ and 09:00 h during eight days per month (four days on each transect) between November, 2011, and October, 2012. During sightings, the animal detected during the surveys were observed using Nikon Monarch $8 \times 42$ DCF binoculars. The surveys were interrupted during days with intense precipitation.

\subsection{Feeding records}

The composition of the diet was defined based on two complementary methods: (i) the observation of feeding behavior along trails and feeding stations, and (ii) the analysis of fecal samples. Behavioral observations were conducted along pre-existing trails, which were walked randomly in order to guarantee the greatest possible number of encounters during fruit-feeding events. Feeding records were collected whenever one or more guans were observed consuming the fruits, flowers or leaves of a given plant species. Whenever the subjects moved to a new feeding resource during the same observation session, a new record was initiated, as proposed by Altmann (1974). Sites at which a concentration of fruiting plants was found were used as observation points, referred to here as feeding stations.

\subsection{Collection of fecal samples}

The fecal samples were collected along the transects and at the feeding stations. The feces were easily identified due to their large size and presence of large seeds that are rarely ingested by smaller birds, as well as their uric acid content, which distinguishes bird feces from those of mammals (Mikich, 2002). The identification of the samples was supported by the observations of the animals' foraging behavior along the transects, where the animals would often defecate.

The fecal samples were stored in lidded plastic containers containing $70 \%$ alcohol for transportation to the Zoology Laboratory of the Cariri Regional University (URCA) in
Crato, Ceará (Brazil). The samples were triaged using a stereoscopic microscope. The samples were removed, rinsed under running water using a $1 \mathrm{~mm}$-mesh sieve for the separation of the items (seeds, leaves, and flowers). The seeds were sun-dried in Petri dishes, and identified through comparisons with material deposited in herbaria. The leaves and flowers were discarded once identified.

\subsection{Collection of plant samples}

Samples of the reproductive parts of all the plants exploited by the guans for their fruit or other structures were collected and prepared as herbarium specimens, for identification with the assistance of specialists, using the classification system of the Angiosperm Phylogeny Group (APG III, 2009). The voucher specimens were deposited in the Dárdano de Andrade Lima herbarium of the Pernambuco Agronomics Institute (IPA) and the Caririense Dárdano de Andrade Lima herbarium (HCDAL) at URCA.

\subsection{Analysis of the diaspores}

Six fruits and seeds were collected randomly from each of five different plants (separated from one another by a distance of at least $10 \mathrm{~m}$ ) representing each of the species identified in the diet of the guans. The length and breadth of each diaspore were measured using a digital caliper. The morphology and coloration of the fruits were classified following the scheme of Barroso et al. (1999).

\subsection{Data analysis}

The density of the guan populations was estimated using the Distance 6.0 software (Thomas et al., 2010). This program identifies a model or detection function that best represents the set of perpendicular distances recorded during the surveys. This function is then used to estimate the proportion of individuals that were not detected during the surveys, ultimately providing an estimate of population density (Buckland et al., 2001; Cullen Junior and Rudran, 2003). The total size of the species' population can be estimated by multiplying the density of the size of the study area. Sighting rates - number of individuals sighted per $10 \mathrm{~km}$ walked - were also calculated, to provide an index of abundance (Strahl and Silva, 1997).

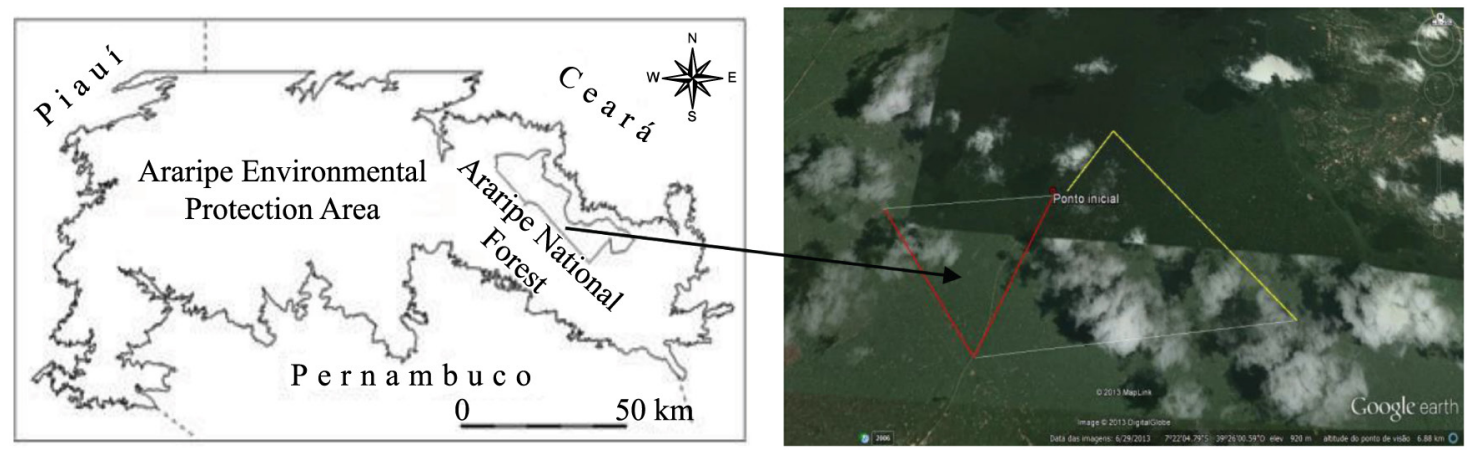

Figure 1. Location of the Araripe Environmental Protection Area (APA-Araripe) and the Araripe-Apodi National Forest. The arrow indicates the study area surveyed in the present study of $P$. superciliaris and P. jacucaca. The red line represents transect 1 and the yellow line, transect 2 . The white lines delimit the estimated area surveyed. 


\section{Results}

\subsection{Abundance, density, and population size}

A total of $384 \mathrm{~km}$ of transect were walked during the present study period, $192 \mathrm{~km}$ on each trail, during which Penelope superciliaris was encountered on 50 different occasions. Penelope jacucaca was not sighted during these surveys.

Based on the Akaike Information Criterion (AIC), the Distance program selected the half-normal model as the best fit for the data (Figure 2), which provided an estimate of 11.66 groups per square kilometer $\left(\mathrm{km}^{2}\right)$, with a CI of 14.55-25.48 and CV of 13.98 (Table 1). Population density was estimated to be 19.17 individuals $/ \mathrm{km}^{2}$. The study area was estimated to cover $6.23 \mathrm{~km}^{2}$ (623 ha).

\subsection{Feeding ecology}

A total of 52 feeding events were recorded during the present study, when the guans ( $P$. superciliaris) were observed consuming the fruits and seeds of 14 different plant species. Most events occurred at heights of up to $5 \mathrm{~m}$ above the ground (Table 2). A total of 241 seeds were

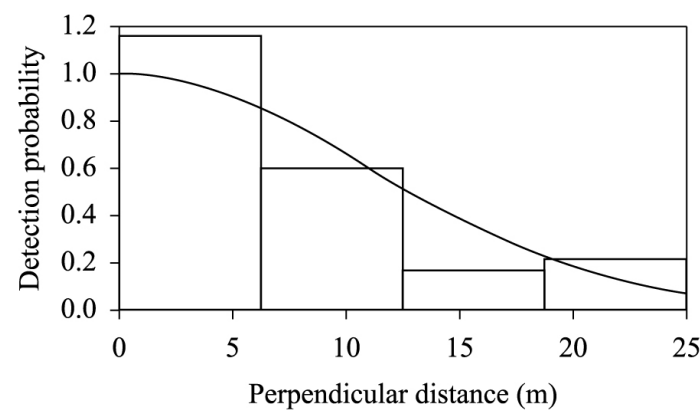

Figure 2. Detection probability function for the population density estimate of Penelope superciliaris. The histogram represents the observed values and the curve, the expected values. found in the 36 fecal samples collected during the study period. Fourteen $(38.8 \%)$ of the fecal samples contained zoochoric seeds, while three $(8.3 \%)$ had leaves and seeds, one $(2.7 \%)$ contained only flowers, and one other $(2.7 \%)$, fragments of insects.

Penelope superciliaris consumed the seeds of 14 plant species belonging to 12 families and 14 genera. Eleven feeding records were collected during the rainy season (December-April), while 15 were collected in the dry season (May-November). The consumption of six plant species - Miconia albicans, Tabernaemontana sp., Buchenavia capitata, Byrsonima sericea, Senna rugosa, and Eugenia puniciflora - was confirmed by 17 of the 36 fecal samples. The species found most frequently in the fecal samples was Buchenavia capitata, observed in nine samples, containing 30 seeds. The Myrtaceae was the most diverse family, being represented by three species, Myrcia multiflora, Psidium sp., and Eugenia punicifolia (Table 3).

\subsection{Characteristics of the fruit consumed by the guans}

Fruit samples of 12 of the 14 species consumed by Penelope superciliaris were collected, measured and identified. Mean diameters ranged from $6.3 \pm 1.35 \mathrm{~mm}$ in Miconia albicans to $29.9 \pm 1.7 \mathrm{~mm}$ in Pisidium sp. (Figure 3 ). Eight $(66 \%)$ of the 12 species analyzed had fruits of between $15 \mathrm{~mm}$ and $30 \mathrm{~mm}$ in length (Table 2). Most fruits ( $\mathrm{n}=5$ or $41.6 \%$ ) were yellow in color, with two species (16.6\%) each having black, green, and red fruits (Table 2). Fleshy fruits of the baccate $(50.0 \%, n=6)$ and drupe $(33.3 \%, \mathrm{n}=4)$ types were the most consumed by P. superciliaris (Table 2).

\section{Discussion}

\subsection{Abundance, density, and population size}

Reliable estimates of density are necessary for the systematic monitoring of populations over time and evaluate the impacts caused by anthropogenic disturbances

Table 1. Population parameters estimated for Penelope superciliaris in the Araripe-Apodi National Forest in Ceará, Brazil.

\begin{tabular}{ccccccc}
\hline Species & $\mathbf{N}$ & $\begin{array}{c}\text { Density } \\
\text { (individuals/(km }{ }^{2} \text { ) }\end{array}$ & $\mathbf{C V}(\%)$ & CI & Total population & $\begin{array}{c}\text { Abundance } \\
\text { (sightings/10 km) }\end{array}$ \\
\hline 50 & 19.17 & 13.98 & $14.55-25.48$ & 119.42 & 0.13 \\
\hline
\end{tabular}

$\mathrm{N}=$ number of sightings; $\mathrm{CV}=$ coefficient of variation; $\mathrm{CI}=95 \%$ confidence interval.

Table 2. Number of plant species consumed by P. superciliaris in the Araripe National Forest, Ceará, Brazil, between November, 2011, and October, 2012, by fruit color, fruit morphology, fruit diameter and records of feeding behavior by foraging height.

\begin{tabular}{cccccccc}
\hline Fruit color & $\begin{array}{c}\text { Number } \\
\text { of plant } \\
\text { species }\end{array}$ & $\begin{array}{c}\text { Fruit } \\
\text { morphology }\end{array}$ & $\begin{array}{c}\text { Number } \\
\text { of plant } \\
\text { species }\end{array}$ & $\begin{array}{c}\text { Mean } \\
\text { diameter } \\
(\mathbf{m m})\end{array}$ & $\begin{array}{c}\text { Number of } \\
\text { species }\end{array}$ & $\begin{array}{c}\text { Foraging } \\
\text { height }\end{array}$ & $\begin{array}{c}\text { Percentage } \\
\text { of records } \\
(*)\end{array}$ \\
\hline Yellow & 5 & Berry & 6 & $5-9$ & 2 & Soil & $8(2)$ \\
Black & 2 & Drup & 4 & $10-14$ & 2 & $<5 \mathrm{~m}$ & $58(15)$ \\
Green & 2 & Pod & 1 & $15-19$ & 3 & $5.1-10 \mathrm{~m}$ & $23(6)$ \\
Red & 2 & Aril & 1 & $20-24$ & 2 & $>10 \mathrm{~m}$ & $12(3)$ \\
Purple & 1 & & & $25-30$ & 3 & & \\
\hline
\end{tabular}

*The numbers represent the quantity of records for each stratum. 
Table 3. Plant species consumed by Penelope superciliaris in the Araripe National Forest between November, 2011, and October, 2012, based on visual records and the analysis of fecal samples.

\begin{tabular}{|c|c|c|c|c|c|c|c|}
\hline \multirow[t]{2}{*}{ Species } & \multirow[t]{2}{*}{ Common name } & \multirow[t]{2}{*}{ Family } & \multicolumn{2}{|c|}{$\begin{array}{l}\text { Foraging } \\
\text { substrate }\end{array}$} & \multicolumn{2}{|c|}{$\begin{array}{l}\text { Type of } \\
\text { record }\end{array}$} & \multirow{2}{*}{$\begin{array}{c}\text { Part } \\
\text { consumed }\end{array}$} \\
\hline & & & Soil & Plant & $\overline{\text { Visual }}$ & Feces & \\
\hline Miconia albicans & canela-de-velho & Melastomataceae & - & - & - & $\mathrm{x}$ & Fruit \\
\hline Tabernaemontana sp* & cajazinha & Apocynaceae & $\mathrm{x}$ & - & $\mathrm{x}$ & $\mathrm{x}$ & Fruit \\
\hline Buchenavia capitata* & maçaranduba & Combretaceae & - & $\mathrm{x}$ & $\mathrm{x}$ & $\mathrm{x}$ & Fruit \\
\hline Byrsonima sericea* & murici & Malpighiaceae & - & $\mathrm{x}$ & $\mathrm{x}$ & $\mathrm{x}$ & Fruit \\
\hline Matayba guianensis & pitomba & Sapindaceae & - & $\mathrm{x}$ & $\mathrm{x}$ & - & Seed \\
\hline Protium heptaphyllum. & amescla & Burseraceae & $\mathrm{x}$ & - & $\mathrm{x}$ & - & Fruit \\
\hline Senna rugosa & besouro & Fabaceae & - & - & - & $\mathrm{x}$ & Fruit \\
\hline Chrysophyllum arenarium & grão-de-galo & Sapotaceae & - & $\mathrm{x}$ & $\mathrm{x}$ & - & Fruit \\
\hline Anacardium microcarpum & cajuí & Anacardiaceae & - & $\mathrm{x}$ & $\mathrm{x}$ & - & Fruit \\
\hline Caryocar coriaceum & pequi & Caryocaraceae & $\mathrm{x}$ & - & $\mathrm{x}$ & - & Flor \\
\hline Eugenia punicifolia* & aperta-cu & Myrtaceae & - & $\mathrm{x}$ & $\mathrm{x}$ & $\mathrm{x}$ & Fruit \\
\hline Myrcia multiflora & cambuí & Myrtaceae & - & $\mathrm{x}$ & $\mathrm{x}$ & - & Fruit \\
\hline Psidium sp. & goiabinha & Myrtaceae & - & $\mathrm{x}$ & $\mathrm{x}$ & - & Fruit \\
\hline Ocotea pallida & louro-urubu & Lauraceae & - & $\mathrm{x}$ & $\mathrm{x}$ & - & Fruit \\
\hline Total: 14 species & & 12 families & & & & & \\
\hline
\end{tabular}

*= species most consumed.

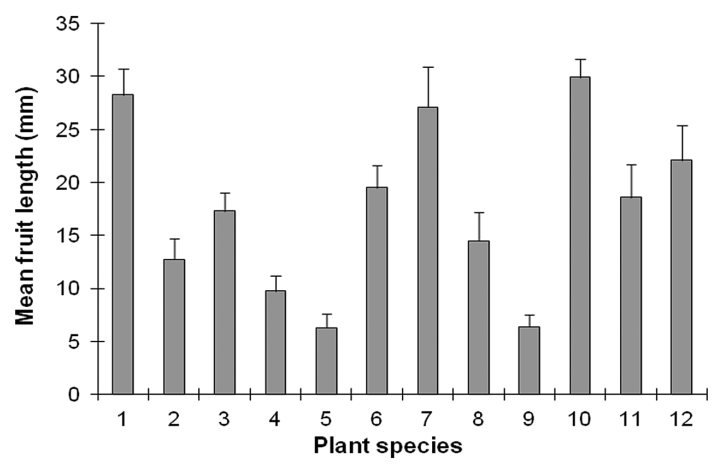

Figure 3. Mean size of the fruits consumed by Penelope superciliaris in the Araripe National Forest between November, 2011, and October, 2012. The vertical lines represent the standard deviation of each mean value. Plant species: 1. Anacardium microcarpum; 2. Senna rugosa; 3. Ocotea pallida; 4. Bryrsonima sericea; 5. Miconia albicans; 6. Tabernaemontana sp.; 7. Buchenavia capitata; 8. Eugenia punicifolia; 9. Myrcia multiflora; 10. Psidium sp.; 11. Matayba guianensis; 12. Protium heptaphyllum.

(Hoyo, 1994). Consistent and comparable population parameters are essential for the planning, implementation, and evaluation of management strategies, as well as conservation measures (Sutherland, 2000).

The population density of guans (Penelope spp.) varies considerably (Setina, 2009), although few data are available for Brazilian populations. In the forested areas of the Brazilian Pantanal wetlands, Bernardo and Desbiez (2011) estimated a density of 4.66 individuals $/ \mathrm{km}^{2}$ for the endangered Bare-faced curassow (Crax fasciolata), which is threatened by hunting and habitat destruction. Bernardo et al. (2011) provided density estimates for the Black-fronted piping Guan (Pipile jacutinga) from 11 protected areas in the Atlantic Forest biome of São Paulo, southeastern Brazil, that varied in area from 11,100 to 150,000 hectares (in comparison with 623 ha in the present study). Density estimates at these sites varied from 0.23 to 16.2 individuals $/ \mathrm{km}^{2}$, with sighting rates of 0.05 to $0.70 / 10 \mathrm{~km}$, and group densities of 0.20 to $9.80 / \mathrm{km}^{2}$, whereas in the present study, values of 19.17 individuals $/ \mathrm{km}^{2}$, 11.66 groups $/ \mathrm{km}^{2}$, and 0.13 sightings $/ 10 \mathrm{~km}$, respectively, were recorded.

Studies of Penelope have been conducted in a number of other South American countries. Estimates of population density for Spix's Guan (Penelope jacquacu) from Manu, Peru, varied between 2 and 19.8 individuals $/ \mathrm{km}^{2}$ (Torres, 1997). In the Andes of southern Ecuador, estimates of the population density of the Bearded Guan (Penelope barbata) in three different types of habitat within a study area of 400 ha varied from 2.3 to 17.1 individuals $/ \mathrm{km}^{2}$ (Jacobs and Walker, 1999). In a study of the Andean Guan (Penelope montagnii) in the Guadera Biological Reserve in Ecuador, Cresswell et al. (1999) recorded densities of 20 individuals $/ \mathrm{km}^{2}$ on farmland, and 40 individuals $/ \mathrm{km}^{2}$ in a 650 hectare tract of primary forest. Kattan et al. (2006) surveyed populations of the Cauca Guan (Penelope perspicax) in two protected areas in Colombia, recording a density of 8.6 individuals $/ \mathrm{km}^{2}$ in one area of $559 \mathrm{ha}$, and 41.6-100 individuals $/ \mathrm{km}^{2}$ in the other area, of 489 ha. In a second study of $P$. perspicax in a 459 hectare protected area in Colombia, Rios et al. (2008) recorded a density of 31 individuals $/ \mathrm{km}^{2}$ in forested areas, and 88 individuals $/ \mathrm{km}^{2}$ in plantations of Andean Oak and Urupán. 
The population density estimated for $P$. superciliaris in the present study was consistent with the values recorded in most of these other studies of cracids. Variations in population parameters may be related to the fragmentation of habitat, resource availability, seasonal migrations, and possibly also minor differences in study methods (Bernardo and Desbiez, 2011). The Araripe National Forest is inserted within a much larger conservation unit (APA-Araripe), covering a total area of $10,000 \mathrm{~km}^{2}$, and it is important to note that the estimates recorded in the present study provide researchers and reserve managers with only an approximate notion of the characteristics of the natural populations that persist in the region. As population parameters are related to the availability of resources, the considerable diversity of habitat types, and presumably also dietary and other resources within both protected areas may influence the movements of $P$. superciliaris within the region.

Groups of $P$. superciliaris may move freely to areas surrounding the National Forest in search of alimentary resources, nesting sites, and areas with reduced hunting pressure, which may all influence population density. Hunting practices in the conservation unit and surrounding areas (Brasil, 2004) may also have a negative impact on population parameters. This is an important question, given that, while population parameters in the Araripe National Forest may be influenced by the movements of individuals in search of resources, they may also reflect the result of the history of hunting both within and around this protected area. While $P$. superciliaris may be considered to be a common bird (BirdLife, 2010), its present-day populations are being impacted increasingly by habitat destruction and unsustainable hunting pressure, in particular within the Caatinga biome. The combination of hunting pressure and habitat destruction has contributed to a rapid decline in cracid populations in recent decades, in particular guans and curassows, which are primarily forest-dwellers (Brooks and Strahl, 2000).

An important point raised by the present study was the absence of the White-browed Guan (Penelope jacucaca) in the surveys conducted in the Araripe National Forest. This species is endemic to the Brazilian Caatinga biome, but is also found in the transition zones with the Cerrado savanna and Atlantic rainforest and is known to occur on the Araripe Plateau (Brasil, 2008). The biology of this species is still poorly-known (Brooks and Fuller, 2006), even though it is classified as threatened with extinction (Machado et al., 2008), given its vulnerability to hunting pressure and habitat disturbance (Silva et al., 2003; Machado et al., 2008). Brooks and Strahl (2000) identified this species as one of the highest priority bird taxa for conservation. The most recent record of the species in the Araripe National Forest (Nascimento et al., 2000; Minns et al., 2010) were obtained in areas of carrasco scrub, savanna, and dry forest, which may account for the lack of records in the present study, which focused primarily on more humid forest formations.

During a study of Lear's Macaw (Anodorhynchus leari) in Serra Branca, in the Brazilian state of Bahia,
Lima et al. (2003) recorded the presence of P. jacucaca frequently in the local Caatinga habitats. In Ceará, the species is known to occur in the Pentecostes Caatinga, and in the Mãe-da-Lua Private Natural Heritage Reserve in the municipality of Itapajé, where populations of more than 50 individuals were observed in 2012 (Redies, 2013).

\subsection{Feeding ecology}

The Araripe National Forest is characterized by a mosaic of vegetation types (Austregesilo Filho et al., 2001), which may favor the production of a diversity of feeding resources for $P$. superciliaris, as recorded in the present study, where feeding was recorded in trees of different heights - some over $10 \mathrm{~m}$ - along the trails surveyed. Forests with good cover are important for most cracids, especially guans and curassows, which are normally observed feeding in the canopy (Mikich, 1996; Guix and Ruiz, 1997; Brooks and Strahl, 2000). In southeastern Brazil, Mikich (2002) observed a preference of $P$. superciliaris for fruit in the upper strata of the forest. At Araripe in the dry season months (August-November), however, the Rusty-margined Guans tended to forage in smaller groups and in the lower strata of the forest and on the ground (pers. obs.).

A number of previous studies have also confirmed a relatively frugivorous diet for $P$. superciliaris throughout the year (Mikich, 1996, 2001; Zaca, 2003), although the consumption of leaves, flowers, and insects was also confirmed in the present study. The available data indicate that these resources may be important alternatives during the dry season and the transition from the rainy to the dry season (Silva and Strahl, 1991). Sick (2001) noted that the guan diet is composed of fruit, leaves, and shoots, and refers to the descent of the animals to the ground to retrieve fallen fruits or to drink water at river margins, where they may also ingest sand. Other cracids, such as the Red-billed Curassow curassow (Crax blumenbachii) may also feed on mollusks, grasshoppers, tree-frogs, and spiders.

In the Itapetinga Municipal Park in Atibaia, São Paulo (southeastern Brazil), Zaca (2003) found that the consumption of leaves and flowers varied significantly $\left(\chi^{2}=61.42 ; p<0.001\right)$ over the 20 months of the study period, with two peaks in the dry season. A number of studies have also recorded animal prey, such as invertebrates in the stomach contents of guans (Théry et al., 1992; Merler et al., 2001). Sick (1970) and Teixeira and Snow (1982) identified a number of the fruit species consumed by Crax blumenbachii. González-García (1994) recorded the consumption of 40 plant species by the Horned Guan (Oreophasis derbianus) in Mexico, Caziani and Protomastro (1994) analyzed the diet of the Chaco Chachalaca (Ortalis canicollis) in Argentina, while Galetti et al. (1997) reported the exploitation of 41 plant species by Pipile jacutinga in the Intervales State Park in São Paulo, Brazil.

Few data are available on the feeding ecology of Penelope. Sick (1970) reported the consumption of the fruit of a number of plant species, such as Virola bicuiba, Byrbicuiba sp., Lecythis pisonis, and Geonoma sp., by Crax blumenbachii and mentioned that these species were also 
exploited by $P$. superciliaris. Mikich (1996) recorded the consumption of Cabralea canjerana by $P$. superciliaris, while Guix and Ruiz (1997) reported the exploitation of Syagrus romanzoffiana by a number of Penelope species, based on observations of feeding behavior and the analysis of fecal samples.

In a study of the diet of $P$. superciliaris at three sites in southeastern Brazil, Mikich (2002) recorded the consumption of 55 species of fruit, of which 21 were recorded during observations and 34 were encountered in fecal samples. In the Itapetinga Municipal Park, also in southeastern Brazil, Zaca (2003) recorded 52 species, 12 through direct observation, and 40 in fecal samples. The number of species recorded in the present study was relatively low in comparison with these previous findings, especially the fecal sample data, although this may have been at least partly related to certain methodological differences among the studies, such as the collection of fecal samples at nighttime roosts during the two previous studies. Despite efforts to locate roosts during the present study, it was not possible to collect fecal samples from these locations. The chances of encountering feces containing seeds at these sites appear to be greater than in general, given that the birds may often use such roosts continually during fruiting peaks (Zaca, 2003).

One other reason that may have contributed to the reduced number of fruit species recorded in the present study is the fact that the Chico Mendes Biodiversity Institute (ICMBio), which administrates the Araripe National Forest, has authorized the harvesting of pequi (Caryocar coriaceum) in this conservation unit by the local populations. This fruit is typical of the Brazilian Cerrado savanna, and is the principal source of income for many of the communities in the area surrounding the national forest. During pequi season, large numbers of harvesters use the trail system of the national forest to locate fruiting trees, and almost certainly interfere with the behavior of the local guans, which probably retire to more isolated and less accessible parts of the area, reducing the potential for observation and the collection of fecal samples.

Another important question here is that, during 2012, Ceará suffered the sixth worst drought recorded since 1950, according to data provided by the Ceará State Foundation for Meteorology and Hydrological Resources. Between January and May, only $352.1 \mathrm{~mm}$ of precipitation was recorded, $50.4 \%$ less than the average for the first five months of the year (FUNCEME, 2012). Climatic variations and changes in environmental variables, such as rainfall and sunlight levels, temperatures, and winds, may affect reproductive phenology and alter fruiting patterns significantly (Laurance et al., 2003). In the present case, the reduced precipitation of the study period may have provoked a marked decrease in the availability of fruit, in particular.

In southeastern Brazil, Zaca (2003) recorded 11 species of the family Myrtaceae in the diet of $P$. superciliaris, and as in the present study, this family contributed the largest number of species included in this guan's diet. Mikich (2002) recorded two species - Campomanesia xanthocarpa and Eugenia florida - in the diet of $P$. superciliaris, while Paccagnella et al. (1994) also recorded this plant family in the diet of the cracid Pipile jacutinga. The importance of the Myrtaceae in the diet of cracids has been reported in other studies, such as those of Théry et al. (1992) and Mikich (2002).

One notable exception recorded in the present study was the consumption of the fruit of the Fourleaf Buchenavia, Buchenavia capitata, which was recorded during observations and in nine fecal samples, with a total of 30 seeds. This species has not been recorded in previous studies of $P$. superciliaris, although it has been reported in the diets of other birds and primates (Weaver, 1991 apud Tabarelli et al., 2004). In the Araripe National Forest, this tree attracts large groups of Rusty-margined Guans between June and August, leading to an increase in group size and observations of feeding behavior (pers. obs.). Local ICMBio staff and residents of the surrounding communities reported that the best period to hunt $P$. superciliaris coincided with the peak Buchenavia fruiting season, when large agglomerations of guans are observed visiting these trees. These observations indicate that Buchenavia capitata is a key species in the ecology of the $P$. superciliaris population in the study area.

\subsection{Fruit characteristics}

Mikich (2002) recorded fruits of between $10 \mathrm{~mm}$ and $100 \mathrm{~mm}$ in size in the diet of $P$. superciliaris, but a predominance of those $20 \mathrm{~mm}$ in size. As in the present study, Théry et al. (1992) reported that most of the fruits consumed by the Marail Guan, Penelope marail were less than $30 \mathrm{~mm}$ in length, a pattern also observed in Pipile jacutinga by Galetti et al. (1997). In southeastern Brazil, Zaca (2003) recorded P. superciliaris consuming fruits varying in size from $0.4 \mathrm{~mm}$ (Miconia cinnamomifolia) to $22.3 \mathrm{~mm}$ (Diospyros inconstans), although most species were between $4 \mathrm{~mm}$ and $16 \mathrm{~mm}$.

In the present study, $P$. superciliaris consumed fruits of a variety of sizes, similar to that recorded by Zaca (2003). The beak of this guan permits the ingestion of both small and principally large fruits. In some habitats, the seeds of large fruits may be less likely to be dispersed than those of smaller fruits, given their avoidance by birds with small beaks (Roda, 2003). Silva and Tabarelli (2000) estimated that approximately one third of the tree species of the Atlantic Forest biome of northeastern Brazil, north of the São Francisco River, may be vulnerable to extinction due to the absence of large birds able to ingest and disperse their seeds. This reinforces the importance of the contribution of $P$. superciliaris and other cracids to the population dynamics of many plant species.

A number of studies have shown that red and black fruits are among the most common in southeastern Brazil, as well as other Neotropical regions and the Old World (Mikich, 2002; Zaca, 2003). As in the present study, however, Théry et al. (1992) found that most of the fruits consumed by Penelope marail were either yellow or black. Fleshy dehiscent, indehiscent, and dry dehiscent 
fruits appear to be the most common zoochoric diaspores (Mikich and Silva, 2001), although Théry et al. (1992) and Zaca (2003) also recorded a predominance of berry and drupe type fruits in their studies.

\section{Conclusions}

The results of the present study provide data on the population size and density of Penelope superciliaris in the Araripe National Forest, and other information relevant to the occurrence of the species in the Brazilian Northeast, given the general lack of studies on cracid ecology. The principal components of the diet of this bird and the morphological characteristics of the fruits consumed are also described. Another important result was the absence of Penelope jacucaca from the study area, which may reflect either a preference for more arid habitats, such as the Cerrado savanna and Carrasco scrub, or anthropogenic impacts on its local populations. An apparently important ecological relationship was identified between $P$. superciliaris and the Fourleaf Buchenavia tree (Buchenavia capitata), which may have a major influence on the behavior and population dynamics of this guan. The results of this study represent an important database for the development of effective strategies of conservation and management for P. superciliaris by the environmental authorities and local communities on both regional and national scales.

\section{Acknowledgements}

We are grateful to the Rural Federal University of Pernambuco (UFRPE), the Biodiversity and Local Knowledge Research Netwrok (REBISA), and the Pernambuco State Science and Technology Foundation (FACEPE) for financial support, through the project "Research Nucleus in Ecology, Conservation, and the Potential of Biological Resources from the semi-arid Region of the Brazilian Northeast" (APQ-1264-2.05/10).

\section{References}

ALTMANN, J., 1974. Observational study of behavior: sampling methods. Behaviour, vol. 49, no. 3, pp. 227-267. http://dx.doi. org/10.1163/156853974X00534. PMid:4597405.

ANGIOSPERM PHYLOGENY GROUP - APG III, 2009. An update of the Angiosperm Phylogeny Group classification for the orders and families of flowering plants: APG III. Botanical Journal of the Linnean Society, vol. 161, no. 2, pp. 105-121. http://dx.doi.org/10.1111/j.1095-8339.2009.00996.x.

AUSTREGESILO FILHO, P.T.A., SILVA, J.A.A., MEUNIER, I.M.J. and FERREIRA R.L.C., 2001. Fisionomias da cobertura vegetal da Floresta Nacional do Araripe, Estado do Ceará. Brasil Florestal, vol. 20, n. 71, pp. 13-21.

BARROSO, G.M., MARIM, M.P., PEIXOTO, A.L. and ICHASO, C.L.F., 1999. Frutos and sementes: morfologia aplicada à sistemática de dicotiledôneas. Viçosa: Editora Universidade de Viçosa. 439 p.
BERNARDO, C.S.S. and DESBIEZ, A.L.J., 2011. Density estimates of the Bare-faced Curassow (Crax fasciolata) in the Brazilian Pantanal. Revista Brasileira de Ornitologia, vol. 19, no. 3, pp. 385-390.

BERNARDO, C.S.S., RUBIM, P., BUENO, R.S., BEGOTTI, R.A., MEIRELLES, F., DONATTI, C.I., DENZIN, C., STEFFLER, C.E., MARQUES, R.M., BOVENDORP, R.S., GOBBO, S.K. and GALETTI, M., 2011. Density estimates of the black-fronted piping guan in the Brazilian Atlantic Rainforest. The Wilson Ornithological Society, vol. 123, no. 4, pp. 690-698. http://dx.doi. org/10.1676/10-140.1

BIRDLIFE INTERNATIONAL - BIRDLIFE, 2010 [viewed 10 June 2013]. Species factsheet: Penelope superciliaris [online]. Cambridge. Avaliable from: http://www.birdlife.org/datazone/ speciesfactsheet.php?id $=77$

BRASIL. Instituto Brasileiro do Meio Ambiente e dos Recursos Naturais Renováveis - IBAMA, 2004. Plano de Manejo da Floresta Nacional do Araripe. Brasília. 318 p.

BRASIL. Instituto Chico Mendes da Biodiversidade - ICMBio, 2008. Plano de Ação Nacional para a Conservação dos Galliformes Ameaçados de Extinção (acaruãs, jacus, jacutingas, mutuns and urus). Brasília. 88 p. Série Espécies Ameaçadas, no. 6).

BROOKS, D.M. and FULLER, R.A., 2006. Biologia and conservação de cracídeos. In: D.M. BROOKS, ed. Conserving Cracids: the most Threatened Family of Birds in the Americas. Houston: Houston Museum of Natural Science, pp. 10-22. Miscellaneous Publications of The Houston Museum of Natural Science, no. 6.

BROOKS, D.M. and STRAHL, S.D., 2000. Curassows, guans and chachalacas: status survey and conservation action plan for cracids 2000-2004. Cambridge: IUCN/SSC Cracid Specialist Group. 182 p.

BUCKLAND, S.T., ANDERSON, D.R., BURNHAM, K.P. and LAAKE, J.L., 1993. Distance sampling: estimating abundance of biological populations. London: Chapman \& Hall. 432 p.

BUCKLAND, S.T., ANDERSON, D.R., BURNHAM, K.P., LAAKE, J.L., BORCHERS, D.L. and THOMAS, L., 2001. Introduction to distance sampling. Oxford: Oxford University Press. 568 p.

CAZIANI, S.M. and PROTOMASTRO, J.J., 1994. Diet of the chaco chachalaca. The Wilson Bulletin, vol. 106, no. 4, pp. 640-648.

CRESSWELL, W., HUGHES, M., MELLANBY, R., BRIGHT, S., CATRY, P., CHAVES, J., FREILE, J., GABELA, A., MARTINEAU, H., MACLEOD, R., MCPHIE, F., ANDERSON, N., HOLT, S., BARABAS, S., CHAPEL, C. and SANCHEZ, T., 1999. Densities and habitat preferences of Andean cloud-forest birds in pristine and degraded habitats in north-eastern Ecuador. Bird Conservation International, vol. 9, no. 2, pp. 129-146. http:// dx.doi.org/10.1017/S0959270900002252.

CULLEN JUNIOR, L. and RUDRAN, L.R., 2003. Transectos lineares na estimativa de densidade de mamíferos and aves de médio and grande porte. In: L. CULLEN JUNIOR, R. RUDRAN and C. VALLADARES-PÁDUA, eds. Métodos de estudos em biologia da conservação and manejo da vida silvestre. Curitiba: Editora UFPR. 652 p.

FUNDAÇÃO CEARENSE DE METEREOLOGIAAND RECURSOS HÍDRICOS - FUNCEME, 2012 [viewed 24 September 2013]. Calendário das chuvas [online]. Ceará. Available from: http:// www.funceme.br/index.php/areas/tempo/calendariodaschuvas

GALETTI, M., MARTUSCELLI, P., OLMOS, F. and ALEIXO, E.A., 1997. Ecology and conservation of the jacutinga Pipile jacutinga in 
the Atlantic forest of Brazil. Biological Conservation, vol. 82, no. 1, pp. 31-39. http://dx.doi.org/10.1016/S0006-3207(97)00004-9.

GONZÁLEZ-GARCÍA, F., 1994. Behavior of horned guans in Chiapas, Mexico. The Wilson Bulletin, vol. 106, no. 2, pp. 357-365.

GUIX, J.C. and RUIZ, X., 1997. Weevil larvae dispersal by guans in southeastern Brazil. Biotropica, vol. 29, no. 4, pp. 522-525. http://dx.doi.org/10.1111/j.1744-7429.1997.tb00047.x.

HOYO, J., 1994. Cracidae (Chachalacas, Guans and Curassows). In: J. HOYO, A. ELLIOTT and J. SARGATAL, eds. Handbook of the birds of the world. Barcelona: Lynx Edicions, pp. 310-363.

JACOBS, M.D. and WALKER, J.S., 1999. Density estimates of birds inhabiting fragments of cloud forest in southern Ecuador. Bird Conservation International, vol. 9, no. 1, pp. 73-80. http:// dx.doi.org/10.1017/S0959270900003361.

KATTAN, G.H., LEÓN, A., CORREDOR, G., BELTRÁN, W. and PARADA, M., 2006. Distribution and population density of the Endangered Cauca Guan Penelope perspicax. Bird Conservation International, vol. 16, no. 4, pp. 299-307. http://dx.doi.org/10.1017/ S0959270906000475.

LAURANCE, W.F., RANKIN-DE-MERONA, J.M., ANDRADE, A., LAURANCE, S.G., D'ANGELO, S., LOVEJOY, T.E. and VASCONCELOS, H.L., 2003. Rain-forest fragmentation and the phenology of Amazonian tree communities. Journal of Tropical Ecology, vol. 19, no. 3, pp. 343-347. http://dx.doi.org/10.1017/ S0266467403003389.

LIMA, P.C., SANTOS, S.S. and ROCHA-LIMA, R.C.F., 2003. Levantamento and anilhamento da ornitofauna na pátria da arara-azul-de-lear (Anodorhynchus leari, Bonaparte, 1856): um complemento ao levantamento realizado por H. Sick, L. P. Gonzaga and D. M. Teixeira, 1987. Atualidades Ornitológicas, no. 112 , pp. 11.

MACHADO, A.B.M., DRUMMOND, G.M. and PAGLIA, A.P., 2008. Livro Vermelho da fauna brasileira ameaçada de extinção. 1st ed. Brasília: Ministério do Meio Ambiente. Vol. 2, 1420 p. Biodiversidade, no. 19

MERLER, J.A., DIUK-WASSER, M.A. and QUINTANA, R.D., 2001. Winter diet of dusky-legged guan (Penelope obscura) at the Paraná River Delta region. Studies on Neotropical Fauna and Environment, vol. 36, no. 1, pp. 33-38. http://dx.doi.org/10.1076/ snfe.36.1.33.8886

MIKICH, S.B. and SILVA, S.M., 2001. Composição florística and fenologia das espécies zoocóricas de remanescentes de Floresta Estacional Semidecidual no centro-oeste do Paraná, Brasil. Acta Botanica Brasílica, vol. 15, no. 1, pp. 89-113. http://dx.doi. org/10.1590/S0102-33062001000100010.

MIKICH, S.B., 1996. Análise quali-quantitativa do comportamento de Penelope superciliaris (Aves, Cracidae). Iheringia: Série Zoologia, vol. 81, pp. 87-95.

MIKICH, S.B., 2002. A dieta frugívora de Penelope superciliaris (Cracidae) em remanescentes de floresta estacional semidecidual no centro-oeste do Paraná, Brasil and sua relação com Eutepe edulis (Arecaceae). Ararajuba, vol. 10, no. 2, pp. 207-217.

MIKICH, S.B., 2001. Frugivoria and dispersão de sementes em uma pequena reserva isolada do Estado do Paraná, Brasil. Curitiba: Universidade Federal do Paraná, 145 p. PhD Thesis.

MINNS, J., BUZZETTI, D., ALBANO, C., GROSSET, A., WHITTAKER, A., and PARRINI, R., 2010. Aves do Brasil, vozes e fotografias. Versão 1.0. Vinhedo: Avis Brasilis. DVD-
ROM. Floresta Atlântica, Cerrado, Caatinga, Pantanal, Campos Sulinos e Costa, vol. 1.

NASCIMENTO, J.L.X., NASCIMENTO, I.L.S. and AZEVEDOJÚNIOR, S.M., 2000. Aves da Chapada do Araripe (Brasil): biologia and conservação. Ararajuba, vol. 8, no. 2, pp. 115-125.

PACCAGNELLA, S.G., ANTONELLI-FILHO, R., LARA, A.I. and SCHERER-NETO, P., 1994. Observações sobre Pipile jacutinga Spix, 1825 (Aves, Cracidae) no Parque Estadual de Carlos Botelho, São Paulo, Brasil. Iheringia: Série Zoologia, vol. 76 , pp. 29-32.

REDIES, H., 2013. Observation on White-browed Guan Penelope jacucaca in north-east Brazil. Cotinga, vol. 35, pp. 61-68.

RIOS, M.M., LONDOÑO, G.A., MUÑOZ, M.C. and KATTAN, G., 2008. Abundancia y endemismo em la pava caucana (Penelope perspicax): ecología o histotia? Ornitologia Neotropical, vol. 19, pp. 295-303

RODA, S.A., 2003. Aves do Centro de Endemismo Pernambuco: composição, biogeografia and conservação. Belém: Universidade Federal de Pernambuco, 520 p. PhD Thesis.

SETINA, V., 2009. Densidad poblacional del paujil copete de piedra (Pauxi pauxi) en la zona amortiguadora del sector sur del Parque Nacional Natural Tama, Norte de Santander. Pamplona: Universidad de Pamplona. Masters Dissertation.

SICK, H., 1970. Notes on brazilian Cracidae. The Condor, vol. 72, no. 1, pp. 106-108. http://dx.doi.org/10.2307/1366485.

SICK, H., 2001. Ornitologia brasileira. 4th ed. Rio de Janeiro: Nova Fronteira. 912 p.

SILVA, J.L. and STRAHL, S.D.,1991. Human impact on populations of chachalacas, guans and curassows (Galliformes: Cracidae) in Venezuela. In: J.G. ROBINSON and K.H. REDFORD, eds. Neotropical wildlife use and conservation. Chicago: University Chicago Press, pp. 37-52

SILVA, J.M.C. and TABARELLI, M., 2000. Tree species impoverishment and the future flora of the Atlantic Forest of northeast Brazil. Nature, vol. 404, no. 6773, pp. 72-74. http:// dx.doi.org/10.1038/35003563. PMid:10716443.

SILVA, J.M.C.S., SOUZA, M.A., BIEBER, A.G.D. and CARLOS, C.J., 2003. Aves da Caatinga: status, uso do habitat and sensitividade. In: I.R. LEAL, M. TABARELLI and J.M.C. SILVA, eds. Ecologia and conservação da Caatinga. Recife: UFPE.

STRAHL, S.D. and SILVA, J.L., 1997. Census methods for cracid populations. In: S.D. STRAHL, S. BEAUJON, D.M. BROOKS, A.J. BEGAZO, G. SEDAGHATKISH and F. OLMOS, eds. The Cracidae: their biology and conservation. Washington: Hancock House Publishers, pp. 26-33.

SUTHERLAND, W.J., 2000. The conservation handbook: research, management and policy. Oxford: Blackwell Science.

TABARELLI, M., SANTOS, B.A. and MELO, F.P.L., 2004. Seed shadow, seedling recruitment, and spatial distribution of Buchenavia capitata (Combretaceae) in a fragment of the Brazilian Atlantic Forest. Brazilian Journal of Biology $=$ Revista Brasileira de Biologia, vol. 66, no. 3, pp. 883-890.

TEIXEIRA, D.M. and SNOW, D.W., 1982. Notes on the nesting of the red-billed Curassow, Crax blumenbachii. Bulletin of the British Ornithologists' Club, vol. 102, pp. 83-84.

THÉRY, M., ÉRARD, C. and SABATIER, D., 1992. Les fruits dans le régime alimentaire de Penelope marail (Aves, Cracidae) en 
Forêt Guyanaise: frugivorie stricte et sélective? Revue d'Ecologie La Terre et la Vie, vol. 47, no. 4, pp. 383-401.

THOMAS, L., BUCKLAND, S.T., REXSTAD, E.A., LAAKE, J.L., STRINDBERG, S., HEDLEY, S.L., BISHOP, J.R.B., MARQUES, T.A. and BURNHAM, K.P., 2010. Distance software: design and analysis of distance sampling surveys for estimating population size. Journal of Applied Ecology, vol. 47, no. 1, pp. 5-14. http:// dx.doi.org/10.1111/j.1365-2664.2009.01737.x. PMid:20383262.
TORRES, B., 1997. Densidades poblacionales de la comunidad de crácidos en el Parque Nacional Manú, Peru. In: S.D. STRAHL, S. BEAUJON, D.M. BROOKS, A.J. BEGAZO, G. SEDAGHATKISH and F. OLMOS, eds. Biology and conservation of the family Cracidae. Washington: Hancock House Publishers, pp. 376-394.

ZACA, W., 2003. Dieta de Penelope superciliaris Spix, 1825 (Aves, Cracidae) em um fragmento de mata semidecídua de altitude no sudeste brasileiro. Uberlândia: Universidade Federal de Uberlândia, 35 p. Masters Dissertation. 